\title{
FAKTOR YANG MEMPENGARUHI PRODUKSI TEMBAKAU (Nicotiana tabacum) DI KECAMATAN SULANG KABUPATEN REMBANG
}

\author{
Dessriana Eka Widi Astuti*1, Suprapti Supardi, Shofia Nur Awami, Dewi Hastuti \\ Program Studi Agribisnis Fakultas Pertanian Universitas Wahid Hasyim Semarang \\ Email: *1dessriana44@gmail.com
}

\begin{abstract}
This study aims to determine the factors that influence tobacco production and determine the level of efficient use of inputs on tobacco production factors. This research uses stratified random sampling method with 63 farmers as respondents. The analysis used is multiple linear regression and calculation of economic efficiency. The results stated that the $R 2$ value obtained through multiple linear regression analysis was 0.890, meaning that the contribution of independent variables (land area, number of laborers, number of seedlings, amount of TSP fertilizer, amount of ZA fertilizer, amount of ZK fertilizer, number of pesticides) to tobacco production was 89 percent, while 11 percent is influenced by other variables outside the model. The results of the F-test were jointly influential and the t-test showed variables that influenced tobacco production including land area, number of laborers, number of seeds, amount of ZA fertilizer and amount of pesticides. Variables such as the amount of TSP fertilizer and the amount of ZK fertilizer had no significant effect. The use of production factors in tobacco farming has not been efficient.
\end{abstract}

Keywords: Efficiency, Production, Tobacco.

\section{PENDAHULUAN}

Kecamatan Sulang merupakan salah satu kecamatan di bagian selatan Kabupaten Rembang yang terletak sekitar 13 kilometer ke arah Selatan dari pusat pemerintahan Kabupaten Rembang. Memiliki luas wilayah 8.454 ha dan jumlah penduduk 9.643 jiwa. Selain tanaman tebu, tembakau merupakan salah satu komoditi pertanian yang banyak dibudidayakan petani di wilayah Kabupaten Rembang. Tembakau adalah tanaman musiman yang tergolong dalam tanaman perkebunan. Tanaman tembakau merupakan salah satu komoditi yang sering dibudidayakan petani Rembang dalam siklus pergiliran tanam selama satu tahun, bergilir dengan padi ataupun palawija. Adapun umur budidaya tembakau atau pemetikan daun tembakau dapat dilakukan pada umur tanaman 90-100 hari, jika penanaman dari umur bibit yang dipindahkan ke lahan pertanaman antara 38 - 45 hari (Susilowati, 2006). Pemanfaatan tanaman tembakau terutama pada daunnya yaitu untuk pembuatan rokok.

Berdasarkan waktu penanaman yang disesuaikan dengan iklim, tembakau dibagi menjadi dua yaitu tembakau musim hujan dan tembakau musim kemarau. Tembakau musim hujan ditanam pada akhir musim kemarau (sekitar bulan Agustus-September) sedangkan tembakau musim kemarau ditanam pada akhir musim hujan (Maulidiana, 2008). Menurut Sahadewo, et all (2020) dilihat dari analisis kuantitatifnya, keputusan petani untuk membudidayakan tembakau dipengaruhi dua variabel yaitu keuntungan usahatani dan 
perubahan/siklus curah hujan yang positif. Demikian pula dengan petani tembakau di Kecamatan Sulang, biasanya tembakau di tanam pada pertengahan tahun, yakni sekitar bulan Mei hingga Juli, utamanya pada bulan kemarau dan panen raya tembakau biasanya pada bulan Agustus hingga Oktober. Tembakau di wilayah Kaliombo Kecamatan Sulang merupakan tembakau berjenis Serumpung. Petani tembakau di Kecamatan Sulang mengusahakan tembakau varietas Serumpung dengan menjalin kemitraan dengan PT Sadhana Arifnusa.

Tingkat kesejahteraan petani sering dikaitkan dengan keadaan usaha tani yang dicerminkan oleh tingkat pendapatan petani. Dalam memasarkan hasil produksi tembakau, petani biasanya menjual dalam bentuk daun atau batang dan ada juga yang menjual dalam bentuk daun yang sudah dirajang dan dikeringkan. Tingkat pendapatan ini dipengaruhi oleh banyak faktor, seperti faktor sosial, ekonomis dan agronomis. Salah satu faktor tersebut yang tidak kalah pentingnya adalah faktor tingkat produksi yang dihasilkan (Nababan, 2009). Sementara pada penelitian Estariza (2013) di Kabupaten Lampung Timur, dengan produksi rata-rata tembakau per hektar sebesar 1.648,07 kg dengan harga rata-rata yaitu Rp27.041,67, sehingga penerimaan petani tembakau sebesar Rp61.445.967,92. Hasil penelitian juga menunjukkan pendapatan petani dari usahatani tembakau per hektar atas biaya tunai sebesar Rp20.934.062,12 dan biaya totalnya sebesar Rp16.820.881,79.

Pada tahun 2019 luas area yang ditanami tembakau di Kecamatan Sulang Kabupaten Rembang yaitu 1.100 ha dan hasil produksinya mencapai 1.650 ton kemudian produktivitas dari tanaman tembakau $1.500 \mathrm{~kg} / \mathrm{ha}$. Luasan lahan tanam paling tinggi berada di Desa Kaliombo yakni dengan luas 184,84 Ha (Badan Pusat Statistik, 2019). Menurut Pertiwi (2013), bahwa peluang yang dapat dilaksanakan dalam rangka peningkatan produksi adalah dengan mengoptimalkan input produksi, antara lain ketersediaan tenaga kerja, penggunaan pupuk kandang, pupuk ZA, pupuk SP36, dan penggunaan pestisida. Berdasarkan hasil penelitian di Desa Tegalroso Kecamatan Parakan Kabupaten Temanggung, bahwa penggunaan pupuk, baik pupuk kandang maupun pupuk buatan seperti ZA dan SP36 serta pemakaian pestisida mempengaruhi produksi tembakau. Variabel penggunaan pupuk merupakan salah satu variabel yang mempengaruhi produksi tembakau tersebut hampir serupa dengan karakteristik faktor yang mempengaruhi produksi tanaman semusim lainnya, misalnya komoditi bawang merah. Penelitian Awami, dkk (2018) menyatakan bahwa variabel yang mempengaruhi produksi bawang merah di Desa Gajah Kecamatan Gajah Kabupaten Demak yaitu variabel luas lahan, jumlah bibit, jumlah pupuk, kepemilikan lahan (status), serta varietas bawang merah. Berdasarkan uraian tersebut, maka tujuan penelitian ini adalah untuk menganalisis faktor - faktor yang mempengaruhi produksi tembakau dan mengetahui tingkat efisiensi penggunaan input pada faktor produksi tembakau di Kecamatan Sulang Kabupaten Rembang.

\section{METODE PENELITIAN}

Metode dasar yang digunakan dalam penelitian ini adalah metode deskriptif yaitu penelitian yang bertujuan untuk membuat deskripsi, gambaran atau lukisan secara sistematis, faktual dan akurat mengenai fakta-fakta, sifat-sifat atau hubungan antar fenomena yang diselidiki (Hamdi dan Bahruddin, 2012). Teknik pengambilan sampel responden dilakukan dengan metode purposive sampling yaitu metode pengambilan sampel dimana populasi yang bersifat heterogen dibagi-bagi dalam lapisan jumlah luas lahan $\left(\mathrm{m}^{2}\right)$. Adapun untuk penelitian 
ini, penulis mengambil sampel responden sebanyak $15 \%$ dari jumlah total populasi yakni sejumlah 63 orang petani tembakau. Data yang diambil adalah data dalam satu periode musim tanam pada bulan Juni sampai dengan September 2019.

\section{Analisis Data}

\section{Faktor-faktor Yang Mempengaruhi Produksi Tembakau}

Faktor-faktor yang mempengaruhi produksi petani tembakau antara lain: luas lahan, jumlah tenaga kerja, jumlah benih, jumlah pupuk TSP, jumlah pupuk ZA, jumlah pupuk ZK dan jumlah pestisida. Adapun langkah yang dilakukan untuk menghitung faktor-faktor tersebut dilakukan dengan membuat regresi berganda dengan persamaan model regresi (Soekartawi, 2020) sebagai berikut :

$\log Y=\log a+b_{1} \log X_{1}+b_{2} \log X_{2}+b_{3} \log X_{3}+b_{4} \log X_{4}+b_{5} \log X_{5}+b_{6} \log X_{6}+$ $\mathrm{b}_{7} \log \mathrm{X}_{7}+\mathrm{e}$

\section{Keterangan :}

Y : Produksi tembakau (kg/musim tanam)

a : Intersep

$\mathrm{X}_{1} \quad$ : Luas Lahan $\left(\mathrm{m}^{2}\right)$

$\mathrm{X}_{2}$ : Jumlah tenaga kerja (HOK)

$\mathrm{X}_{3}$ : Jumlah benih (gr)

$\mathrm{X}_{4} \quad$ : Jumlah pupuk TSP $(\mathrm{kg})$

$\mathrm{X}_{5} \quad$ : Jumlah pupuk ZA $(\mathrm{kg})$

$\mathrm{X}_{6}$ : Jumlah pupuk ZK $(\mathrm{kg})$

$\mathrm{X}_{7} \quad$ : Jumlah pestisida (ml)

e : Variabel Pengganggu

Pengujian model dilakukan melalui dua macam pengujian, yaitu uji asumsi klasik dan uji statistik. Uji asumsi klasik meliputi normalitas, multikolinearitas, autokorelasi dan heteroskedastisitas. Adapun uji statistik dilakukan melalui uji koefisien determinasi $\left(\mathrm{R}^{2}\right)$, uji $\mathrm{F}$ dan uji t.

\section{Efisiensi Penggunaan Faktor Produksi}

Guna mengkaji penggunaan faktor produksi usahatani tembakau telah mencapai efisiensi ekonomi atau belum, digunakan rasio antara nilai produksi marjinal dengan harga masing-masing faktor produksi dengan rumus menurut Soekartawi (2002) sebagai berikut :

$$
\frac{N P M_{X 1}}{P_{X 1}}=\frac{N P M_{X z}}{P_{X z}}=\frac{N P M_{X s}}{P_{X s}}=\frac{N P M_{X 4}}{P_{X 4}}=\frac{N P M_{X s}}{P_{X s}}=\frac{N P M_{X 6}}{P_{X 6}}=1
$$

Keterangan :

$N P M_{x i} \quad=$ Nilai produk marjinal untuk faktor produksi $x i$

$P_{X i} \quad=$ Harga faktor produksi $x i$ 


\section{HASIL DAN PEMBAHASAN}

\section{Gambaran Wilayah dan Karakteristik Responden}

Kabupaten Rembang secara geografis terletak antara $6^{\circ} 30^{\prime}-7^{\circ} 6^{\prime}$ Lintang Selatan dan antara $111^{\circ} 00^{\prime}-111^{\circ} 30^{\prime}$ Bujur Timur. Luas wilayah sebesar 1.014,08 $\mathrm{km}^{2}$, di mana sebagian besar (56,83 persen) wilayah Kabupaten Rembang merupakan dataran rendah di bagian utara Kabupaten Rembang, sedangkan bagian selatan relatif lebih tinggi. Wilayah di bagian selatan ini mempunyai ketinggian antara 101-500 meter dpl (28,29 persen dari total wilayah Kabupaten Rembang) dan sisanya berada pada ketinggian 0-100 m dpl dan > $500 \mathrm{~m}$ dpl. Wilayah Kabupaten Rembang memiliki jenis iklim tropis dengan suhu maksimum tahunan sebesar $33^{\circ} \mathrm{C}$ dan suhu rata-rata $23^{\circ} \mathrm{C}$. Bulan basah di Kabupaten Rembang terjadi selama 4 sampai 5 bulan setiap tahunnya, sedangkan selebihnya termasuk kategori bulan sedang sampai kering. Sementara untuk curah hujan di Kabupaten Rembang dikategorikan sedang, yaitu rata-rata $127 \mathrm{~mm} /$ tahun. Jenis tanah di Kabupaten Rembang diantaranya adalah Mediterial, Grumoso, Aluvial, Andosol dan Regosol.

Responden yang dilibatkan dalam penelitian ini adalah petani tembakau sejumlah 63 petani. Karakteristik responden merupakan gambaran secara umum mengenai umur, pengalaman (lama menekuni pekerjaan), serta jumlah anggota keluarga. Gambaran karakteristik responden disajikan pada Tabel 1. Berdasarkan Tabel 1 diperoleh data bahwa rata-rata umur petani tembakau dalam penelitian ini adalah 48 tahun. Pada umur tersebut petani telah banyak pengalaman dalam bertani tembakau, sehingga telah ahli dalam pengelolaan usahatani tembakau sehingga bisa meningkatkan produksi yang maksimal.

Tabel 1. Data Karakteristik Petani Tembakau Berdasarkan Umur, Lamanya Menekuni Usahatani Tembakau dan Jumlah Anggota Keluarga

\begin{tabular}{lccc}
\hline No & Umur (tahun) & Jumlah Responden (orang) & Persentase (\%) \\
\hline 1. & $31-40$ & 17 & 26,98 \\
& $41-50$ & 17 & 26,98 \\
& $51-60$ & 23 & 36,50 \\
& $61-70$ & 6 & 9,54 \\
\hline Jumlah & & 63 & 100 \\
\hline 2. & LMUT (tahun) & Jumlah Responden (orang) & Persentase (\%) \\
\hline & $1-4$ & 3 & 4,77 \\
& $5-8$ & 44 & 69,84 \\
& $9-12$ & 16 & 25,39 \\
\hline Jumlah & & 63 & 100 \\
\hline 3. & JAK (orang) & Jumlah Responden (orang) & Persentase (\%) \\
\hline & $1-3$ & 15 & 23,80 \\
& $4-6$ & 47 & 74,60 \\
& $7-9$ & 1 & 1,60 \\
\hline Jumlah & & 63 & 100 \\
\hline
\end{tabular}

Keterangan: LMUT : Lama menjalani usahatani tembakau; JAK : Jumlah anggota keluarga Sumber: Analisis Data Primer, 2020.

Rata-rata pengalaman petani dalam mengusahakan usahatani tembakau selama 7 tahun. Hal ini menunjukkan bahwa tanaman tembakau telah cukup lama dibudidayakan secara turun 
temurun di daerah tersebut. Lamanya petani membudidayakan tembakau mempengaruhi keputusan petani dalam mengembangkan usahatani tembakau, semakin lama pengalaman petani dalam usahatani tembakau maka semakin mengetahui kelemahan dan kelebihan usahatani ini, sehingga mampu mengatasi masalah dalam proses budidayanya. Rata-rata jumlah anggota keluarga petani tembakau 4 orang. Jumlah anggota keluarga berpengaruh terhadap motivasi para kepala keluarga untuk memperoleh penghasilan tambahan. Semakin banyak jumlah anggota keluarga, maka semakin mendorong kepala keluarga dalam meningkatkan penghasilan melalui peningkatan jumlah produksi tembakau. Sehingga, jumlah anggota keluarga juga dapat meningkatkan etos kerja para tenaga kerja petani tembakau. Etos kerja yang tinggi juga diikuti dengan motivasi tenaga kerja petani tembakau untuk meningkatkan pendapatan.

Luas lahan (tanah) mempunyai kedudukan penting dalam proses produksi pertanian. Berdasarkan hasil penelitian, bahwa kebanyakan petani tembakau mempunyai luas lahan antara $100-1.000 \mathrm{~m}^{2}$. Kepemilikan lahan oleh petani tembakau di Kecamatan Sulang terperinci pada Tabel 2. Keberadaan luas lahan dan kondisi lahan sangat penting dalam kegiatan usahatani tembakau dan merupakan syarat utama. Lahan yang dimiliki petani berstatus milik sendiri, serta pemakaian luas lahan ini berpengaruh terhadap peningkatan produksi tembakau. Semakin luas lahan yang dimiliki petani, maka tingkat produksi tembakau yang dihasilkan semakin bertambah.

\section{Tabel 2. Identitas Responden Petani Usahatani Tembakau Berdasarkan Luas Lahan}

\begin{tabular}{crr}
\hline Luas Lahan $\left.\mathbf{( m}^{\mathbf{2}}\right)$ & Jumlah (Orang) & Persentase \\
\hline $100-1.000$ & 49 & 77,77 \\
$1.001-2.000$ & 12 & 19,04 \\
$2.001-3.000$ & 2 & 3,19 \\
\hline Jumlah & 63 & 100 \\
\hline
\end{tabular}

Sumber : Analisis Data Primer, 2020.

Tembakau merupakan komoditi yang sistem budidayanya hampir sama di setiap daerah, seperti halnya petani di Kabupaten Rembang, petani di Kabupaten Sampang Madura, juga membudidayakan tembakau. Menurut Verona (2016), tembakau Madura di Kabupaten Sampang juga dikembangkan melalui sistem pergiliran tanaman dengan padi dan palawija. Dalam satu siklus usahatani selama satu tahun pada lahan tembakau sawah, tegal, dan gunung/perbukitan tiap hektar, ternyata budidaya tembakau masing-masing mampu menghasilkan pendapatan Rp 6.192.354,00, Rp 7.162.827,00, dan Rp 5.508.954,00. Pada tiga agro ekosistem tersebut, usahatani tembakau memberikan kontribusi pendapatan sebesar 80 $\%, 73 \%$, dan $63 \%$, dan kontribusi penyerapan tenaga kerja mencapai $59 \%, 67 \%$, dan $76 \%$. Sementara Putri (2015) menyampaikan bahwa pendapatan petani tembakau per musim termasuk kategori menguntungkan. Nilai pendapatan (keuntungan) usahatani tembakau Maesan 2 di Desa Gunungsari Kecamatan Maesan Kabupaten Bondowoso, yaitu sebesar Rp 12.387.619,90 selama 1 musim untuk lahan seluas 1 Ha. Nilai R/C lebih dari satu, yaitu sebesar 1,81 . 


\section{Faktor Yang Mempengaruhi Produksi Tembakau}

Berdasarkan hasil olah data dengan SPSS 16.00 menyatakan bahwa semua variabel sudah terbebas dari uji asumsi klasik meliputi uji normalitas, multikolinearitas, autokorelasi dan heteroskedastisitas sehingga model layak digunakan dalam penelitian. Secara terperinci, hasil olah data regresi tercantum pada Tabel 3.

Variabel faktor - faktor yang mempengaruhi produksi tembakau dalam penelitian ini adalah luas lahan, jumlah tenaga kerja, jumlah benih, jumlah pupuk TSP, jumlah pupuk ZA, jumlah pupuk ZK dan jumlah pestisida. Guna mempermudah perhitungan, dari fungsi awal, kemudian diubah dalam bentuk logaritma linier, untuk menguji pengaruh antara variabel independen terhadap produksi tembakau dapat ditulis dalam persamaan (3) berikut :

$\log \mathrm{Y}=\log \mathrm{a} X_{1} b^{1}, X_{2} b^{2}, \ldots .+e^{u}$

Dimana e $=2,7182$

$\log$ Produksi $(Y)=\log 0,639+0,333 \log \mathrm{X} 1+0,422 \log \mathrm{X} 2+0,343 \log \mathrm{X} 3-$ $0,150 \log \mathrm{X} 4+0,132 \log \mathrm{X} 5+0,048 \log \mathrm{X} 6+0,129 \log \mathrm{X} 7$

Tabel 3. Hasil Analisis Regresi Faktor-faktor Yang Mempengaruhi Produksi Tembakau

\begin{tabular}{llccc}
\hline No & Variabel & Koefisien Regresi & T- Hitung & Prob. Sig \\
\hline 1 & Intersep & 0,639 & 0,851 & 0,398 \\
& Luas Lahan & 0,333 & 3,883 & $0,008^{*}$ \\
& Jumlah Tenaga Kerja & 0,422 & 3,037 & $0,004^{*}$ \\
& Jumlah Bibit & 0,343 & 2,127 & $0,038^{* *}$ \\
& Jumlah Pupuk TSP & $-0,150$ & 2,799 & $0,078^{* * *}$ \\
& Jumlah Pupuk ZA & 0,132 & 2,768 & $0,003^{*}$ \\
& Jumlah Pupuk ZK & 0,048 & 0,641 & $0,524^{\text {ns }}$ \\
Jumlah Pestisida & 0,129 & 2,414 & $0,019^{* *}$ \\
\hline Koefisien Determinasi $\left(\mathrm{R}^{2}\right)$ & 0,890 & & \\
Adjusted R Square & 0,876 & & \\
F hitung & 63,751 & & \\
F tabel & 2,27 & & \\
t tabel & 2,004 & & \\
Durbin Watson & 1,947 & &
\end{tabular}

Keterangan :

* Signifikan pada tingkat kepercayaan $99 \%(\alpha=0,01)$

** Signifikan pada tingkat kepercayaan $95 \%(\alpha=0,05)$

*** Signifikansi pada tingkat kepercayaan $90 \%(\alpha=0,1)$

ns Tidak signifikan

Sumber : Analisis Data Primer, 2020.

\section{Uji Statistik}

Berdasarkan hasil olah data statistik menunjukkan koefisien determinasi $\left(\mathrm{R}^{2}\right)$ sebesar 0,890, sementara Adjusted R Square sebesar 0,876, sehingga proporsi pengaruh variabel bebas terhadap variabel sebesar $87,6 \%$, sedangkan sisanya $12,4 \%$ dipengaruhi oleh variabel lain yang tidak terdapat pada model regresi linier dalam penelitian ini. Berdasarkan uji F-statistik menunjukkan bahwa model regresi yang diestimasi layak dan variabel bebas secara keseluruhan bersama-sama berpengaruh secara signifikan terhadap variabel terikat berupa produksi tembakau. Uji t-Statistik digunakan untuk menguji seberapa jauh pengaruh satu 
variabel penjelas/bebas secara individual dalam mempengaruhi variabel terikat. Berdasarkan hasil analisa dapat diketahui bahwa variabel bebas yang berpengaruh secara nyata (signifikan) terhadap variabel terikat, meliputi: luas lahan, jumlah tenaga kerja, jumlah pupuk TSP, jumlah pupuk ZA dan jumlah pestisida. Adapun variabel bebas berupa jumlah pupuk ZK berpengaruh tidak nyata terhadap variabel terikat berupa produksi tembakau. Selaras dengan hasil penelitian Pertiwi (2013) yang menunjukkan bahwa variabel pupuk ZA dan pestisida, berpengaruh positif dan signifikan terhadap produksi tembakau di Desa Tegalroso Kecamatan Parakan Kabupaten Temanggung.

\section{Efisiensi Penggunaan Faktor Produksi}

Analisis efisiensi digunakan untuk mengetahui apakah penggunaan faktor - faktor produksi tembakau di Desa Kaliombo sudah mencapai efisien atau belum. Berdasarkan Tabel 3 diperoleh nilai koefisien regresi $(\beta)$ masing-masing faktor produksi $<1$. Nilai koefisien regresi tersebut menggambarkan nilai efisiensi secara teknis, artinya penggunaan faktor produksi usahatani tembakau tidak efisien secara teknis. Menurut Budiono (2002) kriteria penilaian efisiensi secara teknis dapat dilihat dari besarnya elastisitas produksi atau nilai koefisien regresi yang diperoleh. Ketentuan efisien jika nilai koefisien sama dengan satu.

Soekartawi (2002) menyatakan bahwa efisiensi produksi sendiri merupakan hasil kali antara seluruh efisiensi harga/alokatif dari seluruh faktor input. Efisiensi produksi dapat diketahui dari perhitungan produk marginal, harga input dan harga produk. Ketentuan jika nilai efisiensi yang didapatkan $\neq 1$ maka penggunaan faktor produksi dapat dikatakan belum atau tidak efisien. Jika nilai efisiensi yang didapatkan $=1$ maka penggunaan faktor produksi dapat dikatakan efisien.

Tabel 4. Hasil Perhitungan Efisiensi Produksi

\begin{tabular}{lcccc}
\hline \multicolumn{1}{c}{ Faktor Produksi } & Koefisien & Xi & NPM/Xi & Keterangan \\
\hline Luas Lahan & 0,333 & 6666,67 & 9,0104 & $\mathrm{BE}$ \\
Jumlah Tenaga Kerja & 0,422 & 145,778 & 3,9893 & $\mathrm{BE}$ \\
Jumlah Benih & 0,343 & 22,619 & 3,5246 & $\mathrm{BE}$ \\
Jumlah pupuk TSP & $-0,150$ & 202,381 & $-1,542$ & $\mathrm{TE}$ \\
Jumlah pupuk ZA & 0,132 & 365,873 & 1,2275 & $\mathrm{BE}$ \\
Jumlah pupuk ZK & 0,048 & 92,063 & 2,4993 & $\mathrm{BE}$ \\
Jumlah Pestisida & 0,129 & 72,222 & 3,5468 & $\mathrm{BE}$ \\
Keterangan & & & & \\
BE "belum efisien" & & & & \\
TE "tidak efisien" & & & & \\
\hline
\end{tabular}

Sumber: Analisis Data Primer, 2020.

Nilai efisiensi produksi yang didapatkan dari faktor produksi luas lahan yaitu sebesar 9,0104 maka dikatakan bahwa penggunaan faktor produksi luas lahan belum efisien karena nilai efisiensi lebih dari 1. Faktor produksi luas lahan merupakan salah satu faktor produksi yang berpengaruh dalam produksi tembakau. Luas lahan dapat mencapai efisiensi produksi bilamana petani dapat mengatur jarak tanam. Menurut Akbar et al. (2011) bahwa pengaturan jarak tanam yang sesuai dapat mengurangi terjadinya kompetisi terhadap faktor-faktor tumbuh tanaman yang mempengaruhi produktivitas tanaman. Hasil penelitian ini juga selaras 
dengan hasil penelitian Hanifah (2017) yang menyatakan bahwa faktor produksi jumlah benih belum efisien secara ekonomi.

Nilai efisiensi faktor produksi tenaga kerja sebesar 3,9893. Nilai efisiensi menunjukkan angka lebih besar dari satu artinya penggunaan faktor produksi tenaga kerja belum efisien. Untuk mencapai efisiensi produksi perlu dilakukan penambahan tenaga kerja yang dapat dilakukan saat pemeliharaan tanaman meliputi pemupukan, pengairan dan pengendalian hama penyakit. Jika jumlah tenaga kerja yang memadai dari proses pengolahan tanah, penanaman, pemeliharaan, panen dan pasca panen maka produksi tembakau dapat meningkat.

Nilai efisiensi yang didapatkan dari faktor produksi benih sebesar 3,5246 maka dikatakan bahwa penggunaan faktor produksi benih belum efisien karena nilai efisiensi lebih dari 1. Benih merupakan salah satu faktor produksi yang menentukan dalam budidaya tembakau. Hasil regresi penelitian ini menunjukkan bahwa jumlah benih berpengaruh terhadap produksi tembakau. Adanya hubungan apabila terjadi penambahan jumlah benih maka produksi tembakau meningkat. Penambahan jumlah benih untuk meningkatkan produksi tembakau harus memperhatikan luas lahan yang tersedia agar dapat mencapai efisiensi penggunaan lahan dan penggunaan benih.

Nilai efisiensi ekonomi faktor produksi pupuk TSP -1,542 maka penggunaan faktor produksi pupuk TSP tidak efisien. Pemberian pupuk TSP berlebihan dapat berakibat pada kelebihan unsur nitrogen pada tanah yang dapat menyebabkan hama pada tanaman. Hal ini sesuai dengan pendapat Hanum (2008), pemberian pupuk nitrogen yang berlebihan dapat memacu perkembangan populasi hama terutama kutu tembakau. Hasil regresi penelitian ini menunjukkan bahwa jumlah pupuk TSP tidak berpengaruh terhadap produksi tembakau. Apabila terjadi penambahan atau pengurangan penggunaan jumlah pupuk TSP tidak berpengaruh terhadap produksi tembakau.

Nilai efisiensi ekonomi faktor produksi pupuk ZA 1,2275 dan pupuk ZK 2,4993 maka penggunaan faktor produksi pupuk ZA belum efisien, diperlukan adanya penambahan input faktor produksi tersebut. Pupuk ZA memiliki kelebihan yaitu dapat memberikan hara sesuai dengan kebutuhan tanaman. Pemberian Nitrogen dapat meningkatkan nilai warna hijau daun dan berhubungan dengan peningkatan hasil tanaman.

Nilai efisiensi ekonomi faktor produksi pestisida 3,5468 maka penggunaan faktor produksi pestisida belum efisien. Penggunaan pestisida yang berlebihan dapat mengganggu pertumbuhan tanaman. Menurut Djojosumarto (2008) pestisida yang hendak digunakan harus dipertimbangkan berdasarkan ketepatannya meliputi tepat guna, waktu, jenis dan dosisnya sebab penggunaan pestisida yang tidak sesuai dapat berdampak pada tanaman serta keseimbangan lingkungan. Hasil regresi penelitian ini menunjukkan bahwa pestisida berpengaruh terhadap produksi tembakau. Apabila terjadi penambahan atau pengurangan penggunaan pestisida dapat berpengaruh terhadap produksi tembakau.

\section{KESIMPULAN DAN SARAN}

\section{Kesimpulan}


Berdasarkan penelitian yang telah dilakukan dapat disimpulkan bahwa Faktor-faktor yang mempengaruhi produksi meliputi: luas lahan, jumlah tenaga kerja, jumlah bibit dan jumlah pupuk ZA. Sementara variabel bebas berupa jumlah pupuk TSP dan jumlah pupuk ZK tidak berpengaruh nyata terhadap produksi tembakau.

Tingkat efisiensi penggunaan faktor - faktor produksi pada usahatani tembakau yang terdiri dari luas lahan, jumlah tenaga kerja, jumlah bibit, jumlah pupuk TSP, jumlah pupuk ZA, jumlah pupuk ZK dan jumlah pestisida belum mencapai efisiensi produksi.

\section{Saran}

1. Petani diharapkan lebih memperhatikan banyaknya lahan dan bibit karena lahan dan bibit merupakan faktor yang mempengaruhi produksi tembakau, hal ini dapat menjadi arahan bagi petani mengoptimalkan pemanfaatan lahan yang dimiliki, sehingga akan meningkatkan produksi tembakau sesuai dengan luas lahan yang dimiliki.

2. Petani sebaiknya lebih memperhatikan dalam perawatan sehingga saat memberikan pupuk serta penanganan hama dan penyakit dapat tepat sasaran. Hasil penelitian diketahui bahwa penggunaan pupuk ZK tidak mempengaruhi produksi tembakau, hal ini dapat menjadi arahan bagi petani menggunakan pupuk sesuai aturan pemakaian yang diinstruksikan sehingga dengan pemakaian pupuk sesuai aturan pemakaian akan meningkatkan kualitas dan kuantitas hasil produksi tembakau.

\section{UCAPAN TERIMAKASIH}

Ucapan terimakasih yang sebesar-besarnya terutama kepada Yth. Alm Prof. Dr. Ir. Suprapti Supardi, yang telah banyak membantu dalam proses bimbingan sehingga penelitian dapat selesai dengan baik dan lancar.

\section{DAFTAR PUSTAKA}

Akbar, B. (2012). Pengaruh Kerapatan Terhadap Pertumbuhan Dan Produktivitas Tanaman Tembakau (Nicotiana tabacum) Varietas Serumpung dan Semboja. Skripsi. Surabaya: Fakultas Biologi dan Ilmu Pengetahuan Alam Institut Teknologi Sepuluh Nopember.

Awami, S. N., Sa'diyah. K \& Subekti, E. (2018). Faktor yang Mempengaruhi Produksi Bawang Merah (Allium ascalonium L) Di Kabupaten Demak. AGRIFO Jurnal Agribisnis Vol. 3 No. 2 November. Aceh Utara: Fakultas Pertanian Universitas Malikussaleh.

Badan Pusat Statistik. (2019). Kabupaten Rembang Dalam Angka. Kabupaten Rembang: Badan Pusat Statistik.

Budiono. (2002). Ekonomi Mikro Seri Sinopsis: Pengantar Ilmu Ekonomi. No.1. Yogyakarta: BPFE.

Djojosumarto, P. (2008). Pestisida dan Aplikasinya, Jakarta: PT. Agromedia Pustaka.

Estariza, E., Prasmatiwi, F.E., \& Santoso, H., (2013). Efisiensi Produksi Dan Pendapatan Usahatani Tembakau Di Kabupaten Lampung Timur. JIIA, Juli Vol. 1 No. 3. 
Hamdi, A. S., \& Bahruddin. E., (2014). Metode Penelitian Kuantitatif Aplikasi dalam Pendidikan. Yogyakarta: Deepublisher.

Hanifah, H., Setiawan, B.M., Prasetyo, E., (2017). Analisis Efisiensi Ekonomi Penggunaan Faktor-Faktor Produksi Pada Usahatani Tembakau Di Kecamatan Getasan Kabupaten Semarang. AGRISOCIONOMICS (Jurnal Sosial Ekonomi Pertanian). 1(1):54-62. Semarang: Universitas Diponegoro.

Hanum, C. (2008). Teknik Budidaya Tanaman. Jakarta: Departemen Pendidikan Nasional.

Maulidiana, N., (2008). Identifikasi Sistem Budidaya Tembakau Deli di PT. Perkebunan Nusantara II (Persero) Kebun Helvetia. Universitas Sumatera Utara: Sumatera Utara.

Nababan, C. (2009). Analisis Faktor Faktor Yang Mempengaruhi Pendapatan Petani Padi Di Kecamatan Tiga Binaga Kabupaten Karo. Medan: USU Press.

Pertiwi, D. S., \& Arianti, F., (2013). Faktor-Faktor Yang Mempengaruhi Produksi Tembakau Rakyat (Studi Kasus Desa Tegalroso Kecamatan Parakan Kabupaten Temanggung). Diponegoro Journal Of Economics. Volume 2, Nomor 1. Tahun 2013. Hal 1-6. Fakultas Ekonomika dan Bisnis Universitas Diponegoro.

Putri, E. A., Suwandari, A., \& Ridjal, J. A., (2015). Analisis Pendapatan Dan Efisiensi Biaya Usahatani Tembakau Maesan 2 Di Kabupaten Bondowoso. JSEP Vol. 8 No.1 Maret 2015. Hal 64-69. Jember. Fakultas Pertanian Universitas Jember.

Sahadewo, G. A., Drope, J; Li, Q., Witoelar, F \& Lencucha, R., (2020). In-and-Out of Tobacco Farming: Shifting Behavior of Tobacco Farmers in Indonesia. Int. J. Environ. Res. Public Health, 17, 9416; doi:10.3390/ijerph17249416 www.mdpi.com/journal/ijerph.

Susilowati, E.Y., (2006). Identifikasi Nikotin dari Daun Tembakau (Nicotiana tabacum) Kering dan Uji Efektivitas Ekstrak Daun Tembakau Sebagai Insektisida Penggerek Batang Padi (Scirpophaga innonata). Skripsi. Semarang: Fakultas Matematika dan Ilmu Pengetahuan Alam Universitas Negeri Semarang.

Soekartawi. (2002). Prinsip Ekonomi Pertanian. Jakarta: Rajawali Press.

Verona, L., \& Tiortosuprobo, S., (2016). Peranan Usahatani Tembakau di Berbagai Agro Ekosistem terhadap Pendapatan Petani dan Kesempatan Kerja di Kabupaten Sampang, Jawa Timur. AGRITECH, Vol. 36, No. 3, Agustus. Hal. 344-351. Yogyakarta. Fakultas Teknologi Pertanian Universitas Gadjah Mada. 